Original scientific paper

ISSN: $2335-0113$

UDC: $575: 636$

DOI: $10.15679 /$ bjwr.v5i1.65

\title{
THE FIRST RECORD OF EUCOLEUS AEROPHILUS IN THE GRAY WOLF (CANIS LUPUS) IN BOSNIA AND ERZEGOVINA
}

\author{
Stevanović Oliver ${ }^{1}$, Trbojević Igor ${ }^{2}$, Paraš Smiljana ${ }^{3}$, Nedić Drago ${ }^{1}$, Trbojević Tijana ${ }^{3}$
}

\begin{abstract}
Summary: This paper represents the first report on the presence of a cardiorespiratory nematodes in the gray wolf from Bosnia and Herzegovina. The heart and lungs with corresponding trachea from wolves that were legally hunted from 2009 to 2019 have been analysed by routine post mortem macroscopical examination. A total of 25 heart samples were examined for the presence of Dirofilaria immitis and Angiostrongylus vasorum, while five lungs with trachea samples were examined for the presence of lung nematodes. There was no confirmed presence of Dirofilaria immitis and Angiostrongylus vasorum, while the presence of species Eucoleus aerophilus was established in one case (20\%). This study confirms that the gray wolf is a source of infection with Eucoleus aerophilus to other natural hosts.
\end{abstract}

Keywords: gray wolf, Eucoleus aerophilus, Bosnia and Herzegovina

\section{Introduction}

Cardiorespiratory nematodes represent an important topic in the parasitology of dogs and cats (Traversa et al., 2010). The new understanding of the spread of cardiorespiratory nematodes in pets is in direct correlation with the appearance of these parasites in wild carnivores: foxes, jackals, wolves and wild cats (Otranto et al., 2015). According to recent studies, some of the most important cardiorespiratory nematodes in canidae in Europe are: Eucoleus boehmi, Eucoleus aerophilus, Crenosoma vulpis, Angiostrongylus vasorum, Filaroides spp., and Dirofilaria immitis (Otranto et al., 2015). Some of these pulmonary nematodes can be found in wild canids, primarily in foxes (Hodžić et al., 2016). Ecological factors, changes in the game population, changes in the landscape and demographic changes in rural areas are the key reasons for most cardiorespiratory nematodes to be transmitted to dogs and/or vice versa (Otranto et al., 2015). Many questions in the epidemiology of parasites are a subject of research and discussion, especially knowing that Eucoleus aerophilus and Dirofilaria immitis have zoonotic potential (Lalošević et al., 2008; Simón et al., 2012).

Parasitology of wild carnivores in Bosnia and Herzegovina $(\mathrm{B} \& \mathrm{H})$ in the previous years has made remarkable progress in research. In the 20th century there were limited data on the occurrence of certain parasitic species in foxes and wolves. Delić et al. (1969) determined the presence of nematodes Filaroides osleri in the tracheal mucosa in the red fox (Vulpes vulpes) and gray wolf (Canis lupus) from the area of Igman Mountain near Sarajevo. Several decades later, the first systematic research was carried out by Hodžić et al. (2016), which established a significant prevalence of Crenosoma vulpis, Eucoleus boehmi and Eucoleus aerophilus in foxes from B\&H. This research is a remarkable contribution to the knowledge of cardiorespiratory nematodes in these carnivores, given the extremely high risk that certain parasitic species can be transmitted to pets (Stevanović et al., 2019a). Other studies of these parasites in wild carnivores present rare findings of clinically significant cardiovascular nematodes in badgers (Meles meles) and

\footnotetext{
${ }^{1}$ Stevanovic Oliver, DVM, Research Associate; Nedic Drago, PhD, Professor, Head of the Center for animal health and food safety, Public Institution Veterinary Institute of the Republic of Srpska „Dr Vaso Butozan“ Banja Luka, Branka Radičevića 18, 78000 Banja Luka, Republic of Srpska, Bosnia and Herzegovina

${ }^{2}$ Paraš Smiljana, PhD, Professor; Trbojević Igor, PhD, Laboratory Head, Faculty of Sciences, University of Banja Luka, Mladena Stojanovića 2, 78000 Banja Luka, Republic of Srpska, Bosnia and Herzegovina

${ }^{3}$ Trbojević Tijana, MSc., Resarch Associate, Ecology Research Association, Mladena Stojanovića 2, 78000 Banja Luka, Republic of Srpska, Bosnia and Herzegovina
} 
wildcats (Felis silvestris). Perostrongylus (Aelurostrongylus) falciformis with significant histopathological lesions in the lung of the badger (Stevanović et al., 2018), and in the wild cat a natural mixed infection with Aelurostrongylus abstrusus and Angiostrongylus chabaudi were recorded (Stevanović et al., 2019b).

Unlike foxes and jackals, investigations on wolves are quite rare. One of the main reasons for a large number of studies on foxes in Europe, and so in B\&H, is because a significant number of parasitological studies have been carried out during the program of rabies control (Hodžić et al., 2015). Another reason for the limited number of studies on wolves can be in hunting bans in some European countries due to the relatively small number of animals (Gittleman et al., 2001; Jeremić et al., 2017). For a long time, wolves were intensely hunted, leading to a reduction in their number in almost all European countries, but today's populations of wolves in Europe are generally recovered and stable (Chapron et al., 2014).

There are several studies on the presence of Angiostrongylus vasorum, which was found in wolves from Italy (Eleni et al., 2014), Spain (Segovia et al., 2001) and Croatia (Hermosilla et al., 2017). Dirofilaria immitis was found in a wolf kept in captivity from Pančevo in Serbia (Gavrilović et al., 2015), then in Bulgaria (Georgieva et al., 2001), Spain (Segovia et al., 2001) and Italy (Pascucci et al., 2007). Trihuroid pulmonary nematodes from genus Eucoleus are also rarely found in gray wolves in Europe. For now, there is evidence that Eucoleus aerophilus is documented in Belarus (Shimalov \& Shimalov, 2000), Poland (Popiolek et al., 2007) and Germany (Lesniak et al., 2017) while nasal eucoleosis caused by Eucoleus boehmi (significant prevalence of 60\%) was diagnosed in wolves from Sweden (Al-Sabi et al., 2018), Portugal (Alho et al., 2016), Italy (Mariacher et al.,2015) and Poland (Zarnowski \& Patik, 1960). Crenosoma vulpis was found in a relatively low prevalence (7.7\%) in wolves in Belarus (Shimalov \& Shimalov, 2000). Data on other cardiorespiratory nematodes in wolves from Europe do not exist.

The Bosnian-Herzegovinian subpopulation of wolves belongs to the Dinaric-Balkan population (Chapron et al., 2014). Wolves in B\&H are hunted species, but in terms of protection and legal regulations they are treated differently. In the Republic of Srpska they are an unprotected species (Anonymous, 2006), while in the Federation of Bosnia and Herzegovina females and young individuals are protected by a seasonal hunting ban, but males are unprotected (Anonymous, 2009). In the period from 2003 to 2013, the gray wolf occupied a territory of about $20,000 \mathrm{~km}^{2}$ (Trbojević, 2016), while the estimated number was about 400 animals for the period 2006-2014 (Trbojević, 2017). According to these estimates, the number of animals was declining. The average total body length for both sexes is $137-177 \mathrm{~cm}$ and body weight $28.5-48$ $\mathrm{kg}$ (Trbojević and Ćirović, 2014). Genetic research has shown that the Bosnian-Herzegovinian subpopulation has more genetic similarity to the wolves from Croatia and to belong more to the "western" Dinarid-Balkan population, than to the wolves population from Serbia and Macedonia (Djan et al., 2014).

This paper examines the presence of the most important cardiorespiratory nematodes in wolves legally hunted from 2009 to 2019 in B\&H. The imperative was placed on the presence of Angiostrongylus vasorum and Dirofilaria immitis in the heart, while the examination of the lungs and tracheas with large bronchi revealed the presence of Crenosoma vulpis, Eucoleus aerophilus and Filaroides.

\section{Materials and Methods}

Samples from hunted wolves were collected on the field from hunters and authors. A total of 25 wolves were examined which were legally hunted in the period from 2009 to 2019. The parasitological examination of wolves included examination of the heart $(N=25)$ and lungs with trachea $(N=5)$. Samples of heart and lung were frozen and stored at $-20^{\circ} \mathrm{C}$ on the Faculty of Sciences (Banja Luka) until parasitological examination. The study included adult individuals, of whom 15 were females and 10 males. The total body length for both sexes was $127.8-177.0 \mathrm{~cm}$, while the body mass was $21.0-48.2 \mathrm{~kg}$.

The samples of the heart and lungs with trachea were examined by routine necropsy. The heart was opened with the scissors so that the interior of the atrium and ventricle chambers were visualized. The trachea was opened longitudinally with scissors up to the bifurcation, and then each individual bronchus was examined. The content of the examined organs was washed under a weak jet of water. If nematodes were present, the samples were carefully taken with a pincette and placed in $2 \%$ formalin until microscopical examination. Nematodes were washed in Amman's lactophenol and determined up to the species level on the basis of morphological and morphometric characteristics. 


\section{Results}

Out of a total of 25 examined heart samples, no presence of cardiopulmonary nematodes Angiostrongylus vasorum and Dirofilaria immitis was recorded. In one case (20\%) in the trachea, the presence of the parasite Eucoleus aerophilus was determined. Macroscopic examination showed no pathological changes in the trachea that may be associated with the presence of parasites (Figure 2). One female specimen of Eucoleus aerophilus was found in male wolf in a poor physical condition (total body length $145.3 \mathrm{~cm}$ and body weight $21 \mathrm{~kg}$ ). The animal was legally hunted in 2016 in Šiprage area, Kotor Varoš municipality $\left(44.483311^{\circ} \mathrm{N}, 17.602316^{\circ} \mathrm{E}\right)$. Locations of hunted and examined wolves are shown in Figure 1.

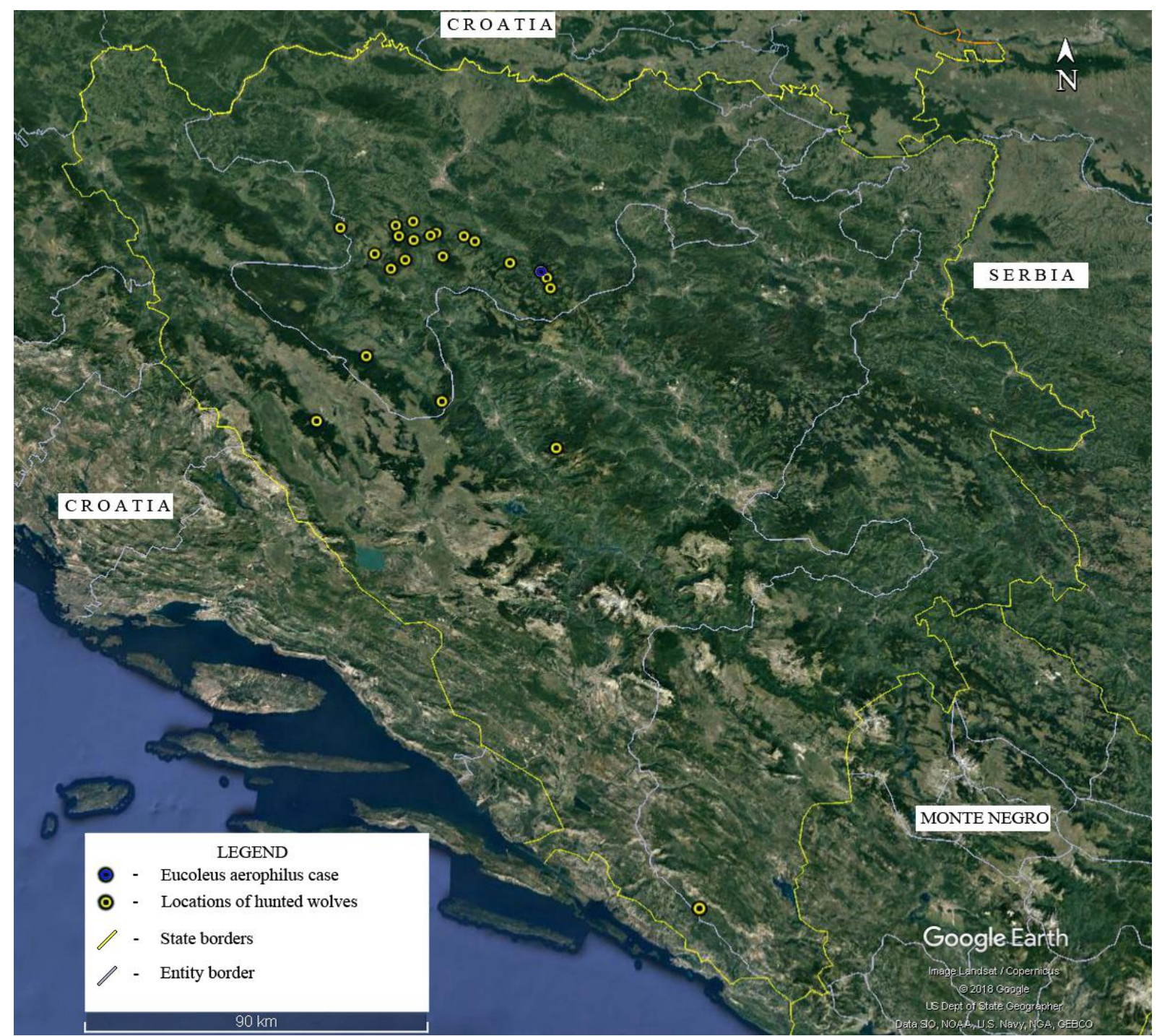

Figure1.Locations of hunted wolves examined for the presence of cardiopulmonary nematodes, from 20092019 in Bosnia and Herzegovina

The nematode has a milky-white colored appearance with a typical filariform appearance, fine structure without macroscopically noticeable differences in thickness between the anterior and posterior extremity of the body. In situ, the parasite had a typical ,zig - zag“ form (Lalošević et al., 2013) (Figure 2). 


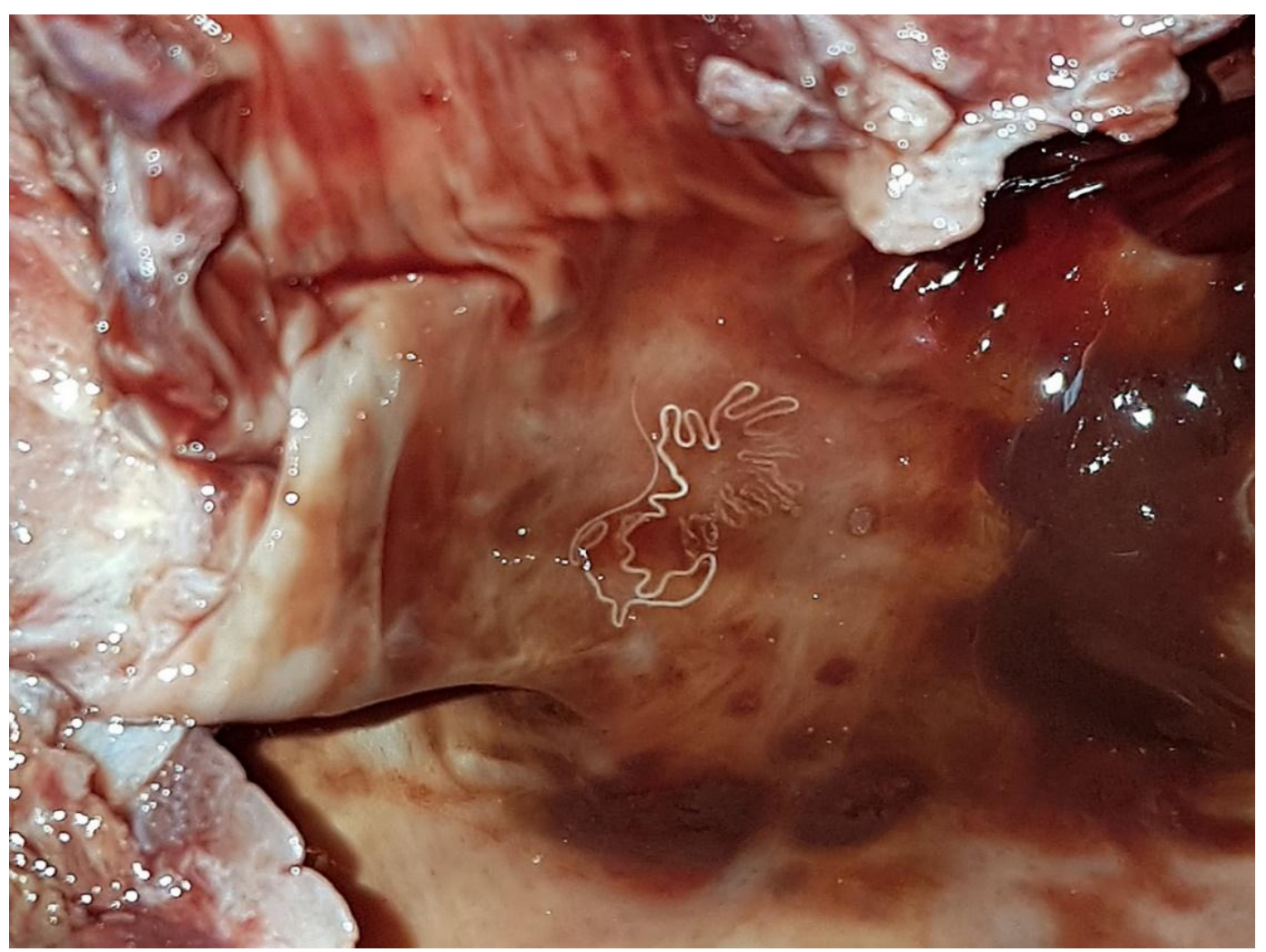

Figure 2. Eucoleus aerophilus in the bifurcation area of the trachea - in situ

On the anterior side of the parasite a simple mouth capsule could be seen i.e. a mouth apparatus that begins with a single tooth and continues into a curved and muscular esophagus. At high magnification (40x), it can be seen that the parasitic cuticle is transversely striated (Figure 3).

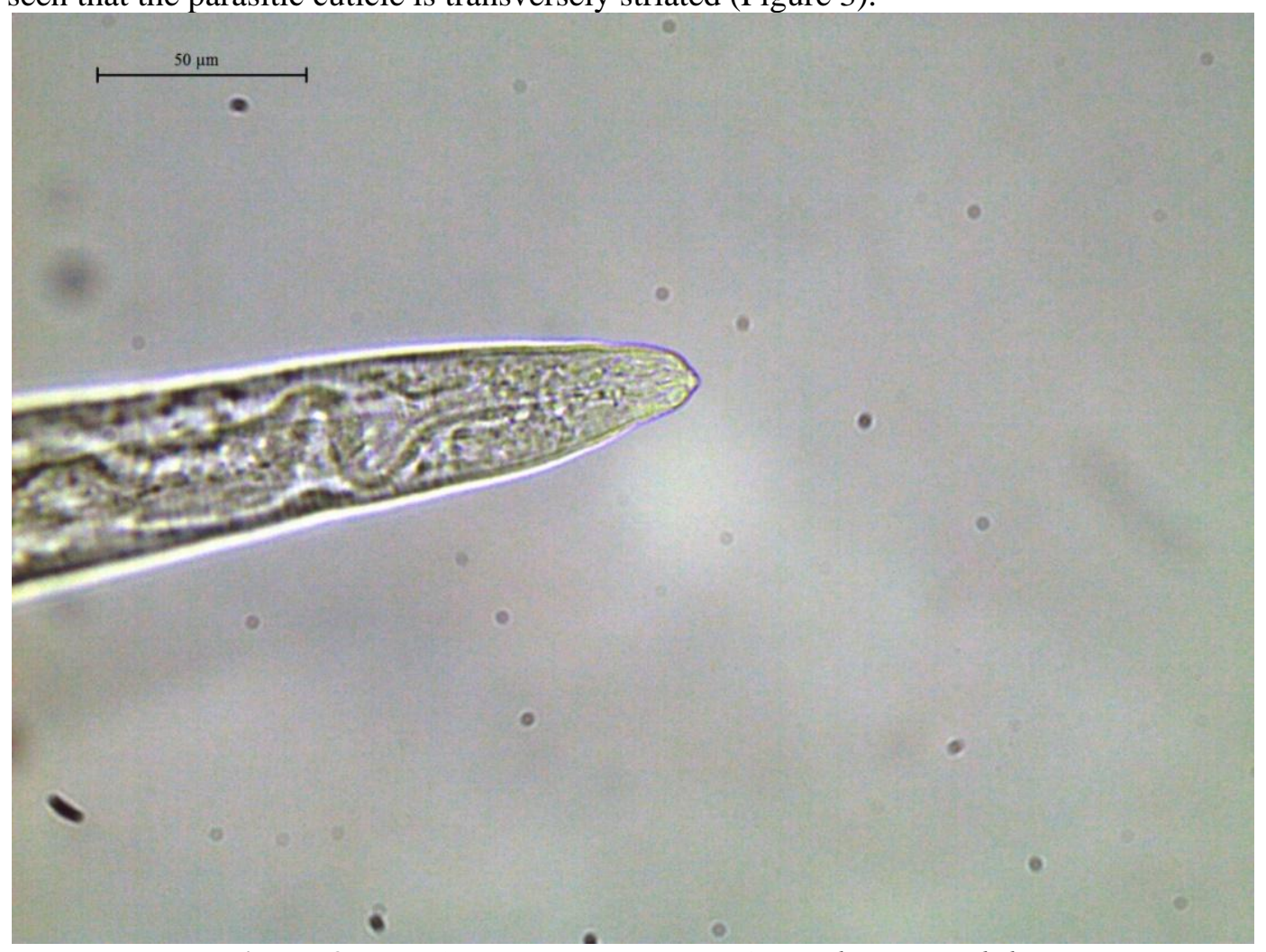

Figure 3. Anterior (head) body part of Eucoleus aerophilus 


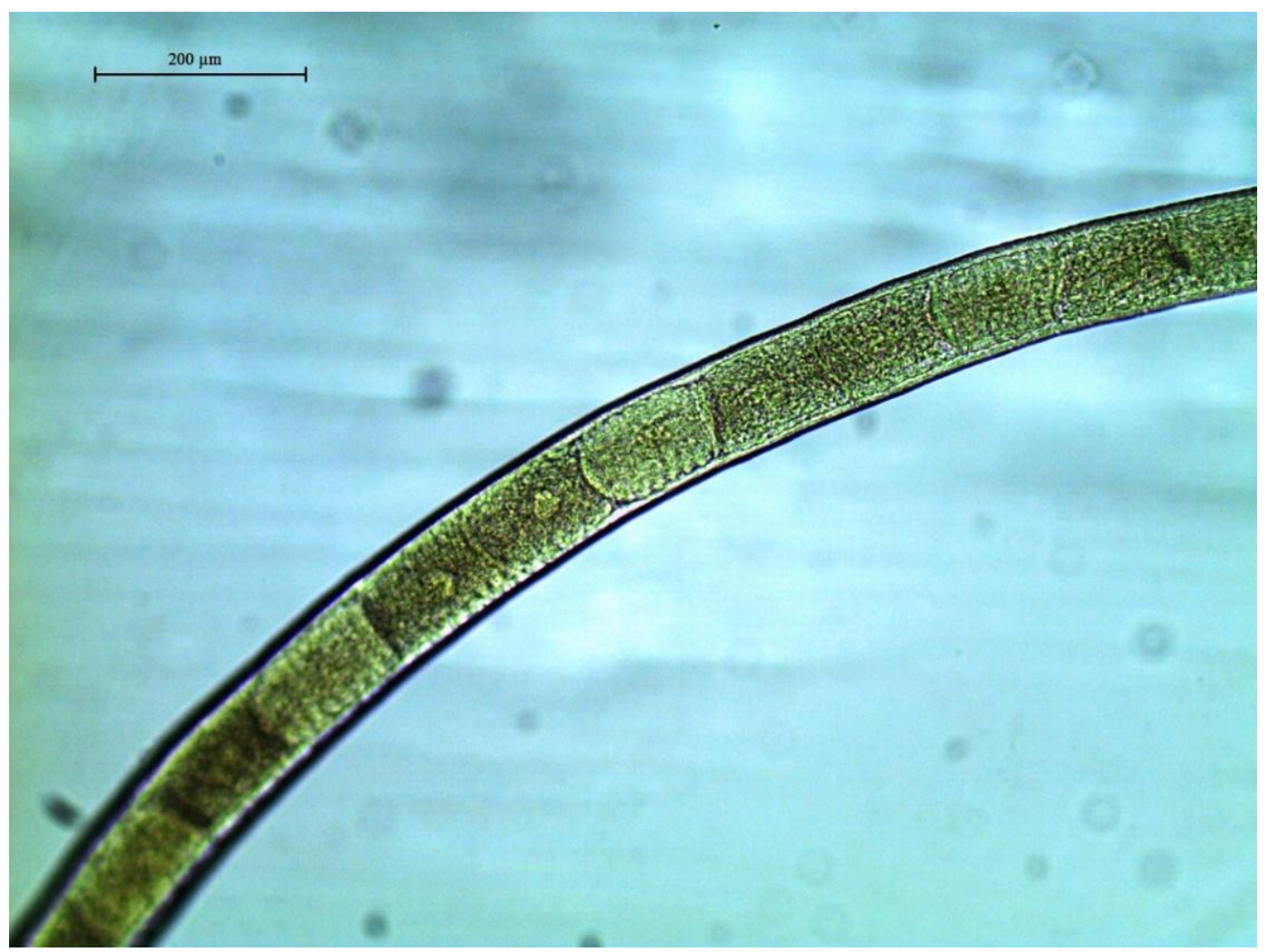

Figure 4. Annular stichocytes of Eucoleus aerophilus

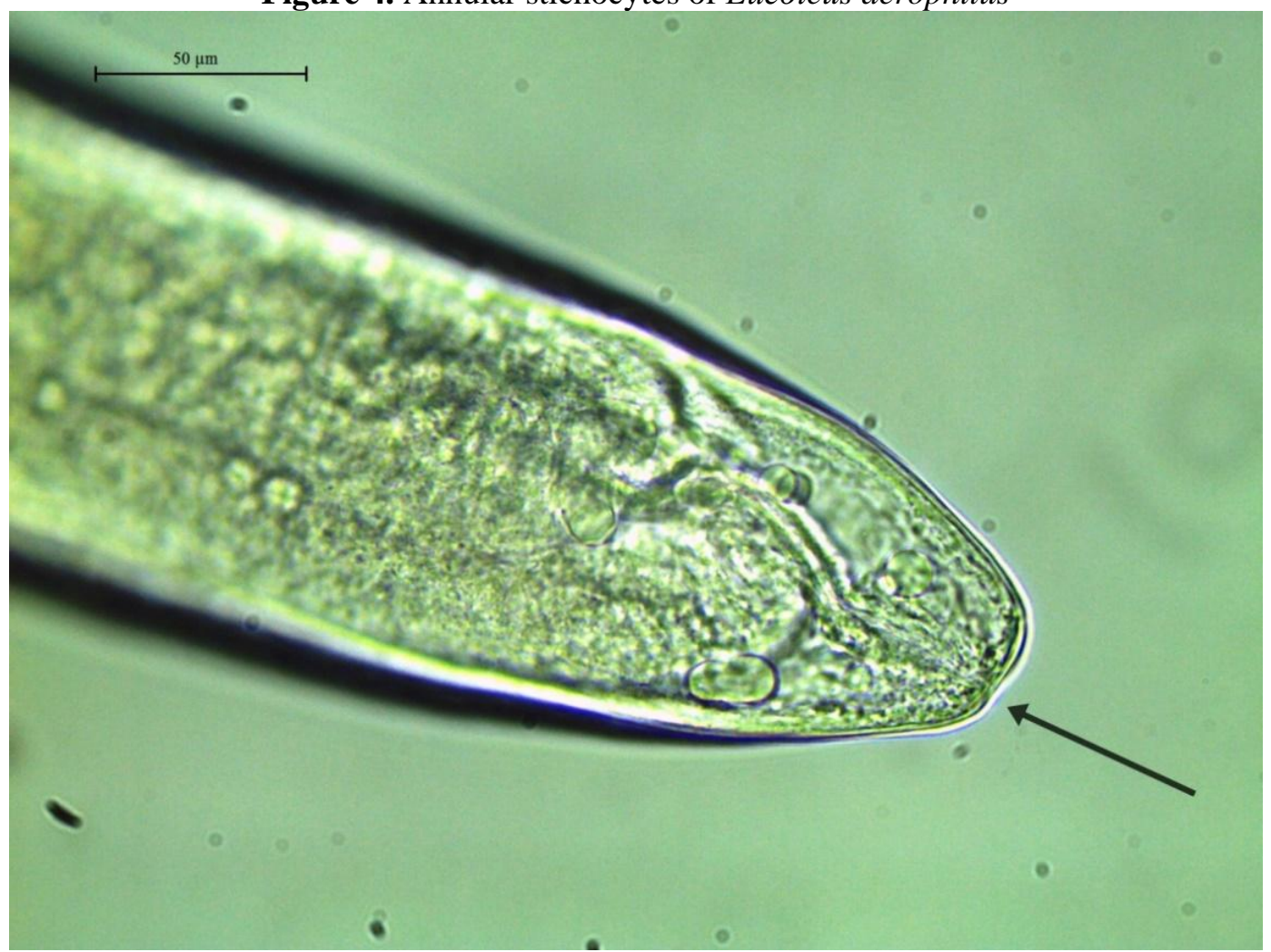

Figure 5. Terminal placed anus (arrow) on the posterior part of the female body of Eucoleus aerophilus.

The esophagus continues in the curved and annular stichocytes (Figure 4), which are generally specific for Capillariidae (Butterworth \& Beverley-Burton, 1980). The posterior part of this parasite was thicker and with a terminally placed anus (Figure 5).

Most of the female body is made up by the uterus filled with typical trihuroid eggs that have a distinctive lemon-like appearance with slightly asymmetrical polar plugs (Traversa et al., 2011).The egg 
surface has a typical network of anastomosing ridges, and the contents filled the entire egg (Figure 6). In the female Eucoleus aerophilus there was a well developed vagina filled with eggs (Figure 7).

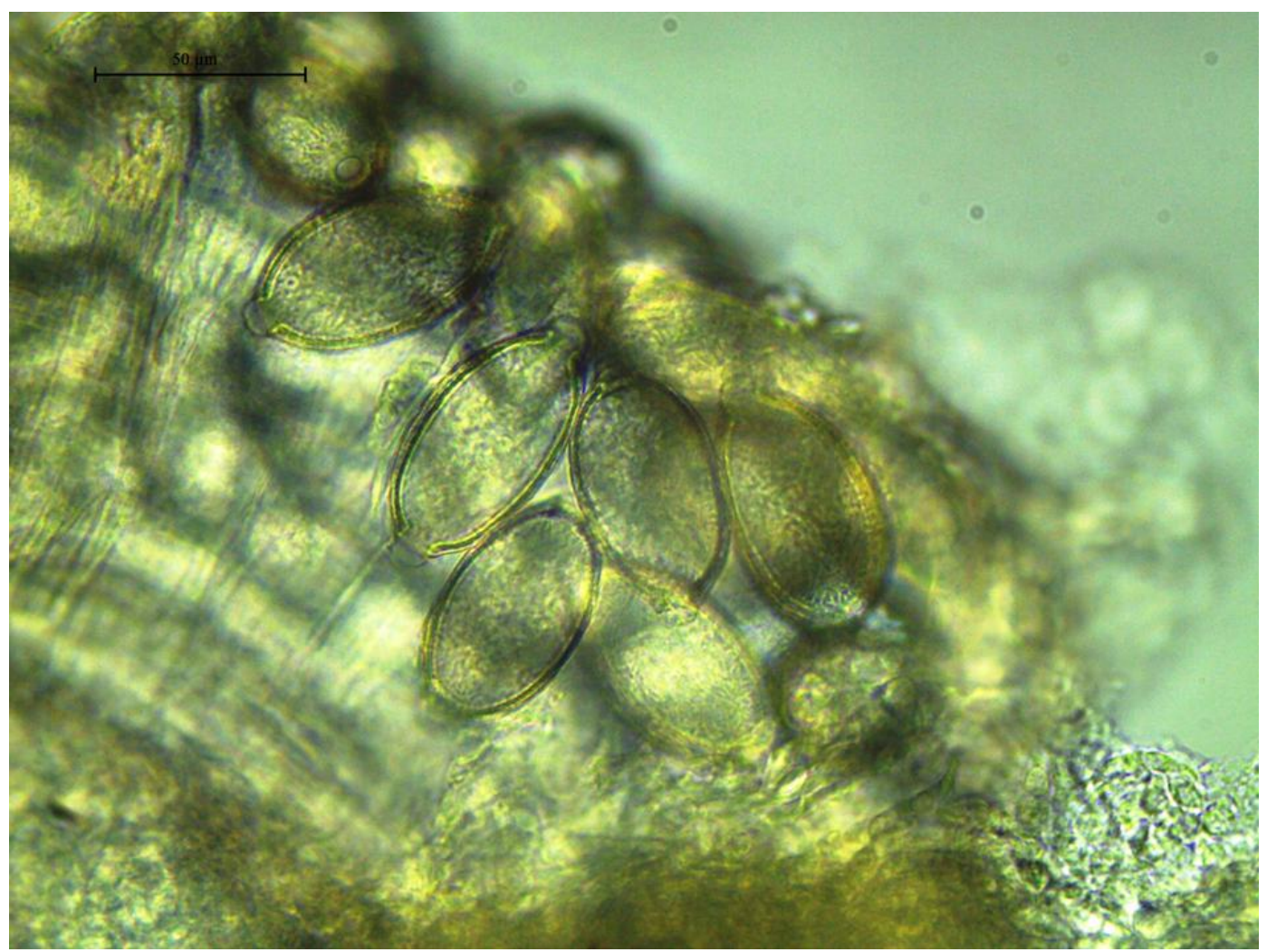

Figure 6. Typical trichuroid eggs in the uterus of Eucoleus aerophilus

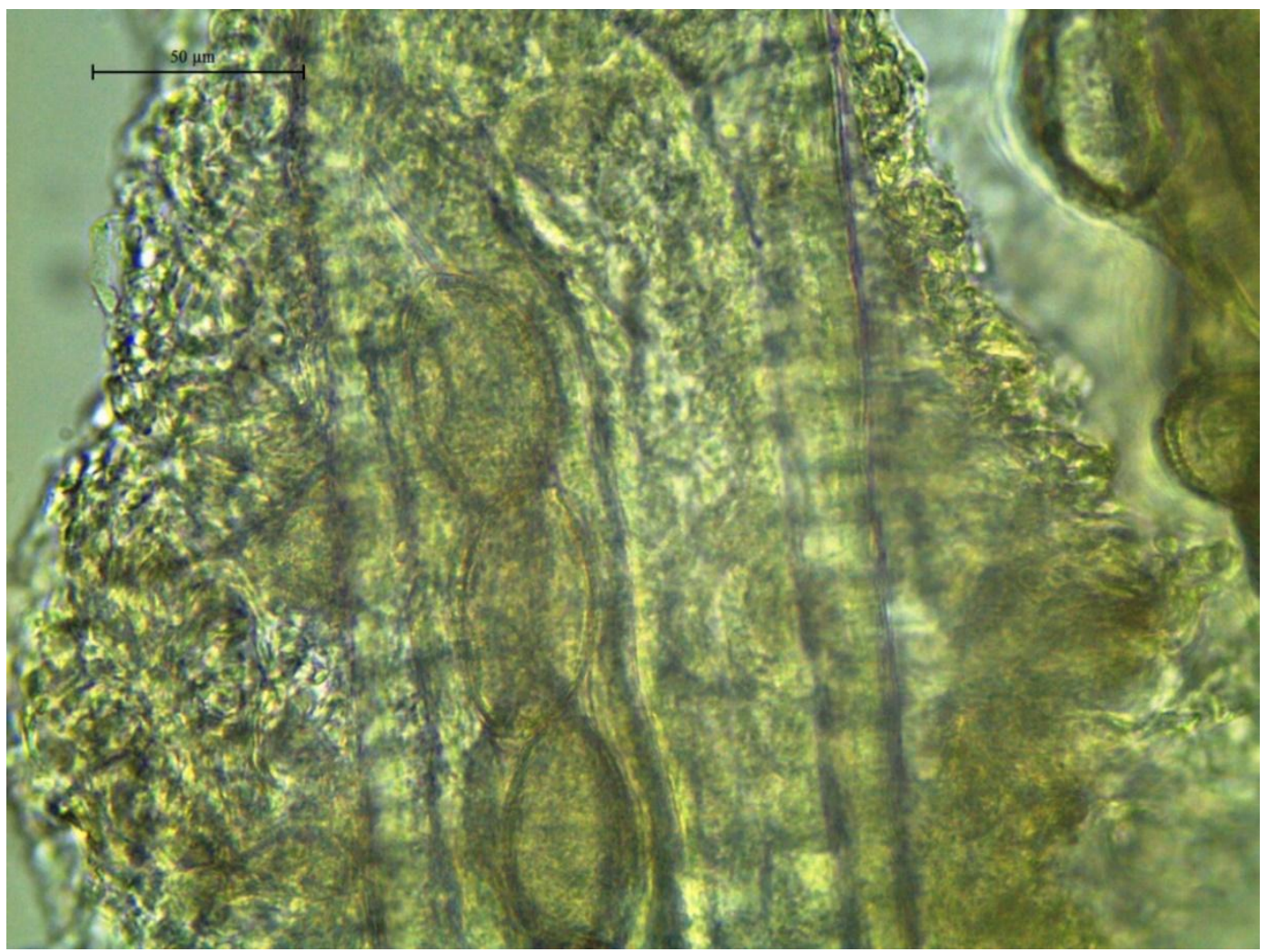

Figure 7. Vagina and vulva with a single egg row in Eucoleus aerophilus 
The definitive diagnosis to the level of the species is based on the morphological descriptions of the adult (Butterworth \& Beverley-Burton, 1980; Moravec, 2000), typical localization of parasites (Supperer, 1953) and morphological characteristics of eggs in the uterus of the female (Traversa et al., 2011).

\section{Discussion}

In this study, Eucoleus aerophilus in the gray wolf (Canis lupus) was recorded in Bosnia and Herzegovina $(\mathrm{B} \& \mathrm{H})$ for the first time. Given that studies on wolves in $\mathrm{B} \& \mathrm{H}$ are rare, this preliminary study is a contribution to knowledge of helmintofauna in carnivores. This work confirms the fact that wolves beside foxes are a natural host for Eucoleus aerophilus (Hodžić et al., 2016). Heartworm -Dirofilaria immitis and French heartworm - Angiostrongylus vasorum in this study have not been confirmed, but this is understandable, as unlike neighboring countries, $\mathrm{B} \& \mathrm{H}$ is not considered an endemic area for these parasites. Epidemiological studies in dogs on the spread of dirofilariosis indicate a relatively low prevalence - about 5\% (Zahirović et al., 2015). Data on the spread of Angiostrongylus vasorum in dogs on the territory of Bosnia and Herzegovina do not exist. Eucoleus aerophilus and Eucoleus boehmi are prevalent in foxes (Hodžić et al. 2016), and for dogs there is only one described clinical case of Eucoleus aerophilus infection (Stevanović et al., 2019a). It is obvious that the infections with cardiorespiratory nematodes are underestimated in dogs, and epidemiological factors that can influence the spread of disease to the wider area are absolutely unknown in our country. For this reason, similar investigations on wild canids need to be encouraged, as new data may point to potential spreading of Eucoleus aerophilus in dogs and possibly cats, especially in rural and mountainous areas of $\mathrm{B} \& \mathrm{H}$.

\section{Acknowledgements}

We thank the hunters of hunting organizations of Bosnia and Herzegovina for cooperation and provision of samples.

\section{REFERENCES}

1. Alho, A.M., Mouro, S., Pissarra, H., Murta, A., Lemos, M., Gomes, L., Lima, C., de Carvalho, L.M. (2016) First report of Eucoleus boehmi infection in a dog from Portugal, Parasitology Research, 115(4), pp. 1721-1725. https://doi.org/10.1007/s00436-016-4932-6.

2. Al-Sabi, M.N.S., Rääf, L., Osterman-Lind, E., Uhlhorn, H. and Kapel, C.M.O. (2018) Gastrointestinal helminths of gray wolves (Canis lupus lupus) from Sweden, Parasitology Research, 117(6),pp. 1891-1898. https://doi.org/10.1007/s00436-018-5881-z.

3. Anonymous, (2006) Law on Hunting of the Federation of Bosnia and Herzegovina, Official Gazette of the Federation of Bosnia and Herzegovina, 4/06.

4. Anonymous, (2009) Law on Hunting of the Republic of Srpska, Official Gazette of Republic of Srpska, 60/09.

5. Butterworth, E.W, Beverley-Burton, M. (1980) The taxonomy of Capillaria spp. (Nematoda: Trichuroidea) in carnivorous mammals from Ontario, Canada, Systematic Parasitology 1(3-4),pp. 211-236.https://doi.org/10.1007/BF00009847.

6. Chapron, G., Kaczensky, P., Linnell, J.D.C. et al. (2014). Recovery of large carnivores in Europe's modern human-dominated landscapes, Science, 346(6216), pp. 1517-1519. https://doi.org/10.1126/science.1257553.

7. Djan, M., Maletić, V., Trbojević, I., Popović, D., Veličković, N., Burazerović, J., Ćirović, D. (2014) Genetic diversity and structuring of the grey wolf population from the Central Balkans based on mitochondrial DNA variation, Mammalian Biology, 79(4), pp. 277282.http://dx.doi.org/10.1016/j.mambio.2014.03.001.

8. Delić, S., Džuvić, A., Kiškarolj, M., Rukavina, J. (1966) Filaroides osleri (Cobbold, 1879) Skrjabin 1933 in a wolf and a fox, Veterinaria (Sarajevo) 15(2), pp. 249-253.

9. Eleni, C., De Liberato, C., Azam, D., Morgan, E.R., Traversa, D. (2014) Angiostrongylus vasorum in wolves in Italy. International Journal for Parasitology, Parasites and Wildlife 3(1), pp. 1214.https://doi.org/10.1016/j.ijppaw.2013.10.003. 
10. Gittleman, L.J., Funk, M.S., Macdonald, D., Wayne, K.R. (Eds.) (2001). Carnivore conservation. Conservation Biology (Cambridge University Press) 5, pp. 1-675.

11. Hermosilla, C., Kleinertz, S., Silva, L.M.R., Hirzmann, J., Huber, D., Kusak, J., Taubert, A. (2017) Protozoan and helminth parasite fauna of free-living Croatian wild wolves (Canis lupus) analysed by scat collection, Veterinary Parasitology, 233, pp.14-19. https://doi.org/10.1016/j.vetpar.2016.11.011.

12. Hodžić, A., Alić, A., Klebić, I., Kadrić, M., Brianti, E., Duscher, G.G. (2016) Red fox (Vulpes vulpes) as a potential reservoir host of cardiorespiratory parasites in Bosnia and Herzegovina, Veterinary Parasitology, 223, pp.63-70.

13. Jeremić, J., Kusak, J., Huber, Đ., Štrbenac, A., Korša, A. (Eds.). (2017).Report on the status of wolf populations in Croatia in 2016. Croatian Agency for the Environment and Nature, Zagreb, pp. 1-89.

14. Lalošević, D., Lalošević, V., Klem, I., Stanojev-Jovanović, D., Pozio, E. (2008) Pulmonary capillariasis miming bronchial carcinoma. American Journal of Tropical Medicine and Hygiene 78, pp. $14-16$.

15. Lesniak, I., Heckmann, I., Heitlinger, E., Szentiks, C.A., Nowak, C., Harms, V., Jarausch, A., Reinhardt, I., Kluth, G., Hofer, H., Krone, O. (2017) Population expansion and individual age affect endoparasite richness and diversity in a recolonising large carnivore population. Scientific Reports7, 41730. https://doi.org/10.1038/srep41730.

16. Moravec, F. (2000) Review of capillariid and trichosomoidid nematodes from mammals in the Czech Republic and the Slovak Republic, Acta Societatis Zoologicae Bohemicae 64, pp. 271-304.

17. Otranto, D., Cantacessi, C., Dantas-Torres, F., Brianti, E., Pfeffer, M., Genchi, C., Guberti, V., Capelli, G., Deplazes, P. (2015) The role of wild canids and felids in spreading parasites to dogs and cats in Europe. Part II: Helminths and arthropods, Veterinary Parasitology, 213,pp. 24-37. https://doi.org/10.1016/j.vetpar.2015.04.020.

18. Pascucci, I., Fico, R., D’angelo, R.A., Serini, S., Camma, C. (2007) First notification in Italy of cardiopulmonary filariosis (heartworm disease) in a wolf (Canis lupus), Veterinaria Italiana 43(4), pp. 851-858.

19. Popiolek, M., Szczęsna, J., Nowak, S., Myslajek, R.W. (2007) Helminth infections in faecal samples of wolves Canis lupus L. from the western Beskidy Mountains in southern Poland, Journal of Helminthology, 81(4), pp. 339-344. https://doi.org/10.1017/S0022149X07821286.

20. Segovia, J.M., Torres, J., Miguel, J. (2001) Helminths in the wolf, Canis lupus, from north-western Spain. Journal of Helminthology, 75, pp. 183-92.

21. Simón, F., Siles-Lucas, M., Morchón, R., González-Miguel, J., Mellado, I., Carretón, E., MontoyaAlonso, J.A. (2012) Human and Animal Dirofilariasis: the Emergence of a Zoonotic Mosaic, Clinical Microbiology Reviews, 25, pp. 507-544.https://doi.org/10.1128/CMR.00012-12.

22. Shimalov, V.V., Shimalov, V.T. (2000) Helminth fauna of the wolf (Canis lupus Linnaeus, 1758) in Belorussian Polesie, Parasitology Research, 86(2), pp. 163-164. https://doi.org/10.1007/s004360050026.

23. Stevanović, O., Trbojević, I., Nikolić, S., Santrač, V., (2018) The first reported case of advanced aelurostrongylosis in Eurasian badger (Meles meles L., 1758) in Bosnia and Herzegovina: histopathological and parasitological findings. Parasitology Research, 117(9): 3029-3032. https://doi.org/10.1007/s13364-018-0365-1.

24. Stevanović, O., Vujanić, D., Dobrijević, M., Nedić, D. (2019a) Clinical Case of Respiratory Eucoleosis in a Dog from Bosnia and Herzegovina. Acta Parasitologica, 64(1): 218-221. https://doi.org/10.2478/s11686-018-00024-6.

25. Stevanović, O., Diakou, A., Morelli, S., Paraš, S., Trbojević, I., Nedić, D., Sladojević, Ž., Kasagić, D., Di Cesare, A., (2019b) Severe Verminous Pneumonia Caused by Natural Mixed Infection with Aelurostrongylus abstrusus and Angiostrongylus chabaudi in a European Wildcat from Western Balkan Area, Acta Parasitologica https://doi.org/10.2478/s11686-019-00029-9.

26. Supperer, R. (1953) Capillaria biohmi spec. nov. eine neue Haarwurmat aus den Stirnh/ilen des Fuchses, Zeitschrifl fiir Parasitenkunde, 16, pp. 51-55.

27. Traversa, D., Di Cesare, A., Conboy, G. (2010) Canine and feline cardiopulmonary parasitic nematodes in Europe: emerging and underestimated. Parasites \& Vectors 3: 62. https://doi.org/10.1186/1756-3305-3-62. 
28. Traversa, D., Di Cesare, A., Lia, R.P., Castagna, G., Meloni, S., Heine, J., Strube, K., Milillo, P., Otranto, D., Meckes, O., Schaper, R. (2011) New insights into morphological and biological features of Capillaria aerophila (Trichocephalida, Trichuridae),Parasitology Research, 109(1), pp. 97-104. https://doi.org/10.1007/s00436-011-2406-4.

29. Trbojević, I. (2016) Distribution of Gray wolf (Canis lupus L., 1758) in Bosnia and Herzegovina, Bulletin of the Faculty of Forestry of the University of Banja Luka, 25(2), pp. 41-49. https://doi.org/10.7251/GSF1625041T

30. Trbojević, I. (2017). State of the wolf population in neighboring countries, Bosnia and Herzegovina. In: Jeremić J., Kusak J., Huber Đ., Strbenac A., Korša A. (Eds.), Report on the status of wolf populations in Croatia in 2016. Croatian Agency for the Environment and Nature, Zagreb (p. 62).

31. Trbojević, I., Ćirović, D. (2015) Sexual dimorphism and population differentiation of the wolf (Canis lupus) based on morphometry in the Central Balkans, North-Western Journal of Zoology, 12,pp. 349-355. Article No.: e151709.

32. Zahirović, A., Omeragić, J., Jažić, A., Rukavina, D. (2015) The occurrence and geographical distribution of canine dirofilariasis in Bosnia and Herzegovina. In 2nd conference on neglected vectors and vector-borne diseases (EURNEGVEC), Izmir, Turkey.

33. Zarnowski, E., Patik, W. (1960) On the independence of the species Thominx böhmi (Supperer 1953) and its occurrence, Acta Parasitologica Polonica, 8,pp. 205 - 214.

Received: 30.04.2019.

Accepted: 29.07.2019.

Stevanović O., Trbojević I., Paraš S., Nedić D., Trbojević T. (2019): The first record of Eucoleus aerophilus in the gray wolf (Canis lupus) in Bosnia and Herzegovina, Balkan Journal of Wildlife Research, 5(1), pp. 19-27. 